\title{
Polish Americans' reception of the „Solidarity” immigration cohort
}

The article discusses mutual relations between the Polish American ethnic group and new immigrants from Poland who were arriving to the United States in the 1980s. The author claims that despite high expectations of both sides the relations were far from harmonious and mutually rewarding, provides examples and formulates reasons thereof. The emphasis is put on the differences between the two groups. The experiences of post-World War II Polish exiles in their contacts with the established Polish diaspora serve as a point of reference.

Keywords: Polish diaspora, Solidarity trade union, immigration, 1980-1990, Poles in USA, Poland under communism.

Approximately quarter million people emigrated from Poland to the United States in the 1980s. From the legal point of view they belonged to three main groups: the minority who used immigrant visas (mostly family members of the US citizens), an undefined number of visitors (estimated at some 150-200,000) who overstayed their non-immigrant visas (so-called wakacjusze - vacationers who came on holiday and did not return for many years), and about 34,000 refugees admitted on the provisions of the Refugee Act of $1980^{2}$. In scholarly literature and in public opinion all of them are associated with the "Solidarity" trade union that operated in Poland legally from August 1980 to December 1981 and then illegally after the imposition of the Martial Law on December 13, 1981 until the collapse

\footnotetext{
${ }^{1}$ Contact: joanna.wojdon@uwr.edu.pl

2 M. Erdmans (2007), Opposite Poles: Immigrants and Ethnics in Polish Chicago, 1976-1990, University Park: Penn State Press, p. 63-64.
} 
of the communist regime in 1989 - despite the fact that according to estimations only about 3,000 of the newly arrived had been actually involved in the "Solidarity" movement ${ }^{3}$. However, majority of immigrants from Poland of the 1980s took advantage of the opportunities that the "Solidarity" opened to the Poles in the West, the opportunities which had not existed earlier and did not repeat later.

The "Solidarity" immigration cohort was the first larger immigration wave from Poland since the arrival of those who had benefitted from the DP Act of 1948 and Refugee Relief Act of 1953. Thus, the group which came shortly after the Second World War can serve as a point of reference in the presentation of the relations between the Polish American ethnic group and the people newly arrived from Poland in the 1980s.

In the 1950s and 1960s strict passport policy of the communist authorities almost completely closed Polish borders. It changed in the 1970s under Edward Gierek, the new leader of Communist party ${ }^{4}$. The number of visitors from Poland in the United States grew significantly. Many were overstaying their tourist visas, taking menial jobs and only eventually looking for opportunities to clarify their immigration status. Some of the immigrants from the "Solidarity" cohort followed the same pattern. If they happened to be visiting the USA in December 1981 when the Martial law was proclaimed in Poland they could use it as an excuse not to return, especially since flight connections with Poland were suspended as the form of the economic sanctions imposed on the Warsaw regime by Reagan's administration. In 1986 the Simpson-Mazzoli immigration law legalized the status of all those who had arrived in the United States prior to January 1, 1982. Thus, the older immigrants from the People's Republic of Poland also profited from the "Solidarity".

The political core of the "Solidarity" immigration came legally under provisions of the Refugee Act of 1980. Those "Reagan's visas" were issued to the Polish refugees who left Poland and were waiting in one of many refugee camps in Italy, Austria or Germany for an opportunity to move overseas (usually to USA, Canada or Australia). Some of the "Solidarity" activists released from the Polish prisons or detention centers were offered one-way passports by the communist authorities in order to leave Poland and thus stop their anti-communist activities. They were also accepted by the US immigration authorities as refugees. Not only did the refugee status solve all the potential problems with immigration authorities but it also

${ }^{3}$ J. Cisek (2003), Polski Komitet Imigracyjny. Polish American Immigration and Relief Committee (PKI-PAIRC) w Nowym Jorku, New York: PAIRC, p. 186. English version of the book: J. Cisek (2006). Polish Refugees and the Polish American Immigration and Relief Committee, Jefferson, NC: McFarland. This estimate is roughly confirmed by the Solidarity activists interviewed by A. Krajewski (1989), Region USA: Działacze Solidarności o kraju, o emigracji, o sobie, London: Aneks.

${ }^{4}$ On the passport policy of the Warsaw regime in the Cold War era see: D. Stola (2010), Kraj bez wyjścia? Migracje z Polski 1949-1989, Warszawa: IPN. 
enabled them to use state and federal support, such as housing allowance, food stamps, free English language classes and job retraining ${ }^{5}$. All this should have made their transition into the American society smoother and less stressful.

This article concentrates, however, not on the relations of the "Solidarity" immigrants with the mainstream American society but with the Polish American ethnic group. According to the theory of Americanization developed by Oscar Handlin, immigrants first become ethnic Americans (in our case: Polish Americans) on their way to becoming Americans ${ }^{6}$. The ethnic group should facilitate their contacts with the mainstream society. It turned out, though, that the contacts of the "Solidarity" immigrants with the Polish American ethnic group were not always as smooth and harmonious as both sides possibly expected.

There are rather few primary sources documenting this process. The newcomers were busy organizing their everyday routines rather than writing diaries. Only recently were the first memoirs of the representatives of this cohort published ${ }^{7}$. In 1986-87 a handful of former "Solidarity" activists who settled down in various parts of the United States were interviewed by Andrzej Krajewski for the book Region USA, published in $1989^{\circ}$. Transcripts of nine other interviews with those who immigrated in the 1980s, conducted by Karen Majewski in Detroit in 1989, have been stored in the Connecticut Polish American Archives in New Britain? Individual stories can be found in various publications, e.g. in a collection of essays of the Polish émigré journalists by Wiesława Piątkowska-Stepaniak ${ }^{10}$.

Mary P. Erdmans in her book Opposite Poles presents an in-depth analysis of the relations between the Polish American "ethnics" (i.e. descendants of the immigrants from the turn of the $19^{\text {th }}$ and $20^{\text {th }}$ century, traditionally called "old Polonia", and World War II émigrés) and new Polish immigrants in Chicago in the early $1980 \mathrm{~s}^{11}$. She includes both the "Solidarity" and pre-"Solidarity" immigration from the "People's" Poland and shows in what way it differed from the older generations of Polish American ethnics. However, to make the situation even more complicated, the files of the organizations supporting "Solidarity" from

${ }^{5}$ See e.g. M. Erdmans, Opposite Poles..., p. 75; A. Krajewski, Region USA..., p. 66, 106-107, 128.

${ }^{6}$ O. Handlin (1973), The Uprooted: The Epic Story of the Great Migrations That Made the American People, Philadelphia: University of Pennsylvania Press, cited by Ch. Hirschman (2004), The Role of Religion in the Origins and Adaptation of Immigrant Groups in the United States, "International Migration Review", Vol. 38, No. 3, p. 1209.

7 C. Karkowski (2016), Na emigracji, Nowy Jork: CreateSpace [printout on request].

8 A. Krajewski, Region USA...

${ }^{9}$ Connecticut Polish American Archives, New Britain, Connecticut (CPAA), Karen Majewski Collection.

${ }_{10}$ W. Piątkowska-Stepaniak (ed.) (2003), Autoportret zbiorowy: Wspomnienia dziennikarzy polskich na emigracji z lat 1945-2002, Opole: Wydawnictwo Uniwersytetu Opolskiego.

${ }^{11}$ M. Erdmans. Opposite Poles... 
Connecticut, Rhode Island, Massachusetts and New York (stored in Connecticut Polish American Archives in New Britain, CT), prove that the pre-"Solidarity" and "Solidarity" immigrants were not the same ${ }^{12}$. The purpose of the organizations: to support "Solidarity", did not mean establishing closer contacts with its members once they arrived in the United States. They were welcomed, sometimes invited to present their first-hand testimonies about life under communism, but usually not involved in any further activities ${ }^{13}$. The newcomers, on their part, regarded all the pre-Solidarity immigrants (those of the 1970s included) as the "old Polonia" and did not distinguish its various layers ${ }^{14}$.

This article aims at reconstructing mutual relations between the immigrants from the "Solidarity" wave and the existing Polish American community of the 1980s. The analysis concentrates on what the latter group did (or did not do) for the new immigrants rather than on what the new immigrants brought to the community. It assumes that the established Polish American community had a position that enabled it to play a decisive role in shaping the relations. Primary sources have been confronted with the models previously elaborated by Stanislaus Blejwas and Mary P. Erdmans.

Apparently, Polonia more willingly supported "Solidarity" in Poland than its former members in the United States. Andrzej Machalica, one of the newcomers, stated it openly in the interview with Andrzej Krajewski: “They help Poland and the 'Solidarity' but they are very distrustful." ${ }^{\prime 5}$ The pattern of the 1940s and 1950s was repeated, when the World War II cohort arrived in the United States and tried to find its place in the established Polish American community. The analysis of that period presented by Stanislaus Blejwas in his article Old and New Polonias: Tensions within an ethnic community ${ }^{16}$ can be applied to the 1980s.

First, Blejwas noticed that unlike the "old Polonia" from the turn of the $20^{\text {th }}$ century, the post-war immigrants did not form a coherent group. The newcomers of the 1980s even less so: they represented various social strata, from the university

12 CPAA, collections: Bogucki family, Dubicka-Morawska, Ślusarek, Solidarity International of Connecticut document the activities of the SI of Connecticut, the New York headquarters of Solidarity International run by Irena Lasota (the documents of this organization can be found also at Lasota's collection at Hoover Institution), Solidarity Support Committee of Rhode Island, Support of Solidarity (Boston).

13 E.g. Protokół z zebrania organizacyjnego Komitetu Solidarności Stanu Rhode Island odbytego w dniu 2 marca 1983 r., CPAA, Ślusarek collection, box 1, folder 25.

${ }^{14}$ E.g. Jan Seń, in: A. Krajewski, Region USA..., p. 150. I follow the perspective of the "Solidarity" cohort while presenting its relations with the Polish American community. However, when referring to the debates of the 1950s and 1960s, the term "old Polonia" is limited to pre-war immigrants.

15 A. Krajewski, Region USA..., p. 107-108.

16 S. Blejwas (1981), Old and New Polonias: Tensions within an Ethnic Community, "Polish American Studies", no. 2, p. 55-83. 
professors to ordinary workers (while the majority of the pre-WWI immigrants were peasants). The "Solidarity" cohort were individuals who made individual decisions to emigrate - sometimes in secret because leaving Poland was regarded by some "Solidarity" activists as desertion and meant betraying those who had to stay ${ }^{17}$. "Wakacjusze" emigrated illegally using tourist passports and visas. They all were dispersed, did not settle down in the old Polish neighborhoods and quite reluctantly joined any organizations. ${ }^{18}$ Anna Sosnowska found out that even until today in New York the opinion prevails that the Solidarity immigrants did not support one another and did not build social networks (which eventually weakened the position of the whole group $)^{19}$, unlike the old Polonia who had well-established networks and institutions.

Second, the cultural and social tastes and aspirations of old Polonia (often derogatively associated by newcomers with kiełbasa, kapusta and polka [sausage, cabbage and polka music ${ }^{20}$ ) did not correspond with those of the post-World War II immigrants who brought the heritage of the inter-war Polish intelligentsia. The "Solidarity" cohort did not match any of the two. They did refer Polishness to more sophisticated issues than traditional food and folk music, but showed little understanding of and appreciation for the pre-war times or the Polish government in exile in London (which the World War II immigrants regarded as the only legal Polish government). For them the "real" Polish culture was developing in Poland, despite the political oppression. According to Mary Erdmans, some of them were not even aware of the existence of the Polish culture in exile ${ }^{21}$.

Third, just as in the post-war years, there was a generation gap. The newcomers were mostly young people, in their twenties or thirties, raising children and prioritizing their family lives ${ }^{22}$; while the World War II cohort was retiring and ethnic activists constantly complained about the aging of their organizations. Mutual empathy was a challenge. Andrzej Machalica who came to San Francisco in 1983 said: "The Polish American Congress in San Francisco is comprised of the old people, who immigrated during the Second World War, and for whom the history had been over at that time. They care about Monte Cassino, Tobruk, Arnheim - the places of their glory. I do not blame them for this but they should move forward." 23

${ }_{17}$ M. Erdmans, Opposite Poles..., p. 66-68; C. Karkowski, Na emigracji..., e.g. p. 15-19; K. Błaszczyk, in: A. Krajewski, Region USA, p. 24; J. Chołodecki, ibid. p. 39; P. Bąkowski, ibid., p. 178.

18 J. Cisek, Polski Komitet...., p. 184.

19 A. Sosnowska (2015), Polski Greenpoint a Nowy Jork. Gentryfikacja, stosunki etniczne i imigrancki rynek pracy, Warszawa: Scholar, p. 210.

20 P. Bąkowski, in: A. Krajewski, Region USA..., p. 176-190, CPAA, Majewski collection, box 1, folder 11, Interview with Henryk Szaniawski, November 22, 1989.

21 M. Erdmans. Opposite Poles..., p. 89-90.

22 P. Bąkowski, in: A. Krajewski, Region USA.., p. 178.

${ }^{23}$ A. Krajewski, Region USA..., p. 108 [my translation - JW.] 
Forth, the language was a barrier between the cohorts. In general, the English proficiency of the "Solidarity" immigrants was higher than that of the post-World War II immigrants when they had arrived in the USA. Most of the newcomers, however, still had to learn a lot in order to communicate freely ${ }^{24}$ while the "old Polonia" in the 1980s was using English as a working language in the organizations and parishes. The "Solidarity" immigrants were fluent in Polish and could hardly understand why the others were not. As Machalica (from the "Solidarity" cohort) said: "I told them that I did not regard as Poles the people who tell us to learn English in a few months because this is America and they do not have time to translate." 25 Even if some of the representatives of the older generations of Polish Americans spoke Polish it did not necessarily bridge the gap. The Polish language used by each of the immigration cohorts: pre-World War I immigrants, World War II exiles and the immigrants of the 1980s was different. The former sounded archaic to the newcomers, while the Solidarity immigrants seemed to be influenced by communism, especially to the World War II immigrants ${ }^{26}$. On the tapes from the meetings of a Polish American organization from Milwaukee taking place in the 1980s, one can hear the exchanges of opinions in both good and bad Polish and good and bad English which makes the discussions hardly comprehensible for anyone ${ }^{27}$.

Fifth, there were divergent expectations from each side that the other one was not going to accept. The Poles arriving to the United States in 1980s hoped to have their entry to the American society facilitated by the Polish community. ${ }^{28}$ But, to cite the president of the Polish American Congress Aloysius Mazewski replying to one of the newcomers who asked for assistance: "Polonia did not wish to donate for that"29. Among the Polish Americans a belief prevailed that America offers so many opportunities to everyone that one should just take them. It is enough to work hard and anyone can get anything they want so there was no real need to help those who were in America if they could help themselves so easily. Such an attitude was expressed already in 1956 by Józefa Rzewska from the American Committee of the Resettlement of the Polish Displaced Persons who wrote to one of the then-newcomers who had been disillusioned by the American realities and decided to re-emigrate to Belgium: "[In the USA] one can work and live as never before. You do not have all the conveniences immediately but who was supposed

${ }^{24}$ See e.g. C. Karkowski, Na emigracji..., p. 121-130; A. Krajewski, Region USA.., p. 66.

25 A. Machalica, in: A. Krajewski, Region USA..., p. 107-108.

${ }^{26}$ M. Erdmans. Opposite Poles..., p. 115-118.

${ }^{27}$ University of Wisconsin-Milwaukee Archives, Polish American Congress, Wisconsin Division: Records, 1948-2003.

28 A. Sosnowska, Polski Greenpoint..., p. 177. The interviewees of A. Sosnowska often complained on the weakness of the Polish American organizations that failed to assist them on the new job market. They envied the Jewish Americans. See also Jan Seń in: A. Krajewski, Region USA..., p. 149.

${ }^{29}$ Immigration History Research Center, Minneapolis, Minnesota, Mazewski papers, box 51, folder 1, Aloysius Mazewski to Jakub Radziejewski, June 7, 1982. 
to arrange those conveniences for you? [...] You won in a lottery to get here and you are [dare to be] too tired to overcome the nostalgia towards your friends." ${ }^{30}$

Janusz Cisek in his book on the Polish American Immigration and Relief Committee finds the newcomers' image of America distorted by popular movies and urban legends which made them expect to get too much and too easily ${ }^{31}$. Piotr Bąkowski, one of the immigrants interviewed in 1986/87 by A. Krajewski, blamed both communist propaganda and the Voice of America for presenting an idealized image of Polonia while the newcomers were immediately confronted with the tough reality ${ }^{32}$. Ewa Ślusarek from the Solidarity Support Committee of Rhode Island asked the personnel of the US embassy in Warsaw not to give false promises to the released political prisoners that the US government would "supply every possible need for the émigré and his family" ${ }^{33}$.

On the other hand, the leaders of the Polish American community expected the newcomers to join and reinvigorate the existing ethnic organizations, press and parishes $^{34}$. They neglected the fact that those organizations were concentrated on ethnic issues and answered the needs of the "old Polonia", totally odd to the newcomers. For instance, as Mary Erdmans noticed in her book, the newly arrived were interested in the English language and not Polish language classes and would carry the banners with "Solidarity" rather than with a portrait of Pulaski on the Third of May parade ${ }^{35}$.

In general, unlike their post-World War II predecessors, the "Solidarity" immigrants were not particularly interested in the organizational activities ${ }^{36}$. They preferred to act individually. Newcomers' pre-occupation with the material issues and their disinterest in the Polish American organizations annoyed the old Polonia. In one of his books, Stanislaus Blejwas cited a question posed by one of the newcomers when asked if he would like to join an organization: "And how much do they pay there?"37

${ }^{30}$ Immigration History Research Center, Minneapolis, Minnesota, Polish American Congress, box 24, folder 127, letter to F. Cieślak, September 20, 1956, [my translation - J.W.].

31 J. Cisek, Polski Komitet Imigracyjny..., p. 196.

32 P. Bąkowski, in: A. Krajewski, Region USA..., p. 177. The research in the press of the People's Poland proves that although the general image of the United States and of the Polish Americans was quite negative, and sometimes overtly black, the press constantly addressed the myth of America as an immigrants' paradise. Moreover, when the readers rejected the communist propaganda, they also denied any critical remarks concerning the USA, and the more critical the image was the more fiercely it was rejected - see J. Wojdon (2014), Myths Pertaining to Polish Americans in the Press of the People's Poland, "Ad Americam”, vol. 15, p. 81-89.

${ }_{33}$ CPAA, Ślusarek collection, folder 2, box 2, E. Ślusarek to Claudine Schneider (US Representative), undated letter.

${ }^{34}$ See e.g. CPAA, Majewski, box 1, folder 10, Interview with A. Dolata, October 26, 1989.

35 M. Erdmans, Opposite Poles..., p. 119-121.

36 Ibid., p. 99-111.

37 S. Blejwas (2005), The Polish Singers Alliance of America, 1888-1998: Choral Patriotism, Rochester: University of Rochester Press, p. 179. 
There were exceptions. "Freedom for Poland" was an organization founded by the "Solidarity" immigrants aiming at collecting and distributing support for the anti-communist opposition in Poland. Brotherhood of Dispersed Solidarity Members intended to facilitate the contacts and create a support framework for the newcomers who settled down all around the United States.

Moreover, it should be noted that none of the immigration cohorts from the past undertook political activities in its entirety. As Idesbald Goddeeris recently argued, even the members of Polish "Great Emigration" of the 1830s for the most part rejected any political activities in exile and concentrated on everyday economic issues, not on the struggle for the independence of Poland. No more than 5-10 per cent remained involved in politics ${ }^{38}$. In the internal documents of the organizations of the World War II cohort one can also find constant complaints on insufficient and constantly diminishing membership and involvement of members in organizational activities ${ }^{39}$.

Some of the new immigrants tried to join the existing organizations, including the Polish National Alliance and Polish American Congress. On the local level, they formed e.g. a group "August '80" within the Polish National Alliance in Chicago ${ }^{40}$ and a Lech Wałęsa group of PNA in San Francisco ${ }^{41}$. Jan Seń, a former Solidarity activist from the Wrocław region, told A. Krajewski about his success in joining the Solidarity International in Connecticut ${ }^{42}$ and Andrzej Dolata informed Karen Majewski about his good relations with the Polish Americans in Ann Arbor ${ }^{43}$. On the national level the old issue of leadership and influence re-emerged, however. Once they joined, the newcomers wanted to have some influence, especially on the issues concerning Poland and the "Solidarity" movement and then complained that old Polonia did not look for such advice or for new leaders but rather for file and rank due-paying members. One of the most active representatives of the "Solidarity" cohort, Jarosław Chołodecki, in his interview in Region USA expressed his deep dissatisfaction with the fact that the leaders of the Polish American Congress did not want to use the expertise of the newcomers in formulating the policy towards Poland and despite the agreement reached between the "Solidarity" activists who

38 I. Goddeeris (2016), Spór o emigrację Polską w XIX w. -odpowiedź autora, "Kwartalnik Historyczny", Vol. 123, no. 2, p. 321-326;

39 J. Wojdon (2017), Building the Community of the Post-World War II Polish Political Exiles in Chicago - Mutual Aid Association of the New Polish Immigration, in: A. Małek and D. Praszałowicz (eds), The United States Immigration Policy and Immigrants' Responses: Past and Present, Franfurt am Main: Peter Lang, p. 169-185, based mostly on the papers from the collection of Kazimierz Łukomski at University of Illinois, Chicago.

${ }^{40}$ M. Wierzyński, Druga połowa życia in: W. Piątkowska-Stepaniak W. (ed.), Autoportret zbiorowy..., p. 163 .

41 A. Machalica, in: A. Krajewski, Region USA..., p. 108.

42 A. Krajewski, Region USA..., p. 150.

${ }^{43}$ CPAA, Majewski collection, box 1, folder 10, interview with A. Dolata, October 26, 1989. 
settled down in the United States and the Polish American Congress in January 1987, the PAC did not invite any representative of the "Solidarity" cohort to the Polish American delegation for a meeting at the White House on February 19, 1987 (when Ronald Reagan revoked the economic sanctions against Poland) nor to the meetings of the board of directors of the Polish American Congress ${ }^{44}$. With the exception of the PAC vice-president Kazimierz Łukomski, there was little understanding of the aspirations of the newcomers among the PAC leaders, despite the fact that many of them were representing the post-World War II cohort and had experienced similar problems themselves. Anna Sosnowska noticed in the $21^{\text {st }}$ century that well-established Polish American leaders still had no respect for the newcomers and did not regard them as part of the community that they would have liked to identify with ${ }^{45}$.

The lack of empathy might be attributed to the following factors. First, the material status of the newcomers and their survival strategies did not earn them respect. The old leaders felt superior to the newly arrived, who were poor, had no position and hardly spoke English ${ }^{46}$. As the time passed, the situation improved. Czesław Karkowski noticed that each month brought some progress, which was especially visible when new people were coming from Poland and starting their American life from scratch ${ }^{47}$.

Second, the prominent position in the Polish American ethnic organizations was the lifetime achievement of the World War II émigrés for which they had been struggling since their arrival in the United States, in order to fulfill what Anna Jaroszyńska-Kirchmann called "the exile mission" of providing Poland with independence ${ }^{48}$. It took them years to become presidents or vice-presidents of the state divisions of the Polish American Congress. No wonder they did not want to give up this influence to the newcomers ${ }^{49}$.

Third, they did not always share the same political views as the newly arrived. In general, both old and new immigrants agreed that abolishing the communist regime was the ultimate goal of Polish diaspora and of the democratic opposition in Poland. Their opinions about the regime differed, however. The World War II exiles did not recognize it as a legitimate Polish government and regarded the Polish People's Republic as a territory under Soviet occupation. Any form of co-operation

${ }^{44}$ A. Krajewski, Region USA..., p. 39-40.

${ }_{45}$ A. Sosnowska, Polonijny Greenpoint..., p. 129.

${ }^{46}$ Ibid.

${ }^{47}$ C. Karkowski, Na emigracji..., p. 265-266.

48 A. Jaroszyńska-Kirchmann (2004), The Exile Mission: The Polish Political Diaspora and Polish Americans, 1939-1956, Athens (Ohio): Ohio University Press.

49 To cite Maciej Wierzyński, a Polish journalist who emigrated in the 1980s to Chicago and then to New York: “...for many people of his [Łukomski's, i.e. World War II immigrants] generation the Solidarity cohort were rivals to the honors of dubious value"; see: Piątkowska-Stepaniak W. (ed.), Autoportret zbiorowy..., p. 163; also J. Chołodecki in: A. Krajewski, Region USA..., p. 41. 
with the regime was treated with suspicion if not totally condemned. The most devoted "steadfasts" (niezłomni) did not even visit Poland in order to avoid any contact with the regime administration (e.g. with the consulate) ${ }^{50}$. On their part, the immigrants from the communist-ruled Poland felt that they had lived in Poland and not in the Soviet colony. They did not regard all the communists as enemies. Some of the new immigrants had even been members of the Communist Party for some time. The pre-occupation of "the steadfasts" with anti-communism annoyed some of the newcomers ${ }^{51}$.

Such an attitude made them look suspicious from the point of view of the leaders of the World War II immigration who had always been afraid of the communist infiltration. The former Displaced Persons had been thoroughly screened by the US immigration services before getting visas (which prolonged the procedure of their admission to the United States at the turn of the 1940s and 1950s) ${ }^{52}$ while the "Solidarity" immigrants were not. Realizing that the regime could place its agents among new immigrants (which indeed was happening), the "steadfasts" would prefer to keep all of them away from the decision-making bodies as a preventive measure. It was noticed by the newcomers ${ }^{53}$. Such a mistrust did not help build good relationships. The suspicion and accusations of being communist spies and agents never stopped ${ }^{54}$. It turned out, however, that this cautiousness was not fully effective. I would not totally trust a Polish intelligence officer from the 1980s who claims that the secret services of the People's Poland had excellent knowledge about the activities of Polish Americans and could get any information requested by their bosses in Warsaw ${ }^{55}$; but one can point to the biography of Wojciech Wierzewski, who provided the communist intelligence with detailed reports of his Indiana university faculty fellows in the late 1970s. Several years later he became the editor-in-chief of the Polish

${ }^{50}$ See e.g. A. Jaroszyńska-Kirchmann, The Exile Mission...; P. Kardela (2000), Stanisław Gierat 1903-1977: Działalność społeczno-polityczna. Szczecin: Albatros; idem (2015), Stowarzyszenie Polskich Kombatantów w Stanach Zjednoczonych w latach 1953-1990, Olsztyn-Białystok: IPN.

51 See e.g.: CPAA, Majewski collection, box 1, folder 8, interview with Basia Delawska-McQuaid, November 16, 1989.

${ }^{52}$ Memo to America-the DP Story: The Final Report of the United States Displaced Persons Commission (1952), Washington: Government Printing Office.

${ }^{53}$ Barbara Kalabińska confirmed such an attitude she and her husband (a Polish journalist, later associated with Radio Free Europe, the author of the speech of Lech Wałęsa in the US Congress in 1989) experienced when they arrived in Washington, D.C. (talk in Kraków, June 2017); C. Karkowski, Na emigracji..., p. 217.

${ }^{54}$ See e.g.: W. Piątkowska-Stepaniak (ed.), Autoportret zbiorowy..., p. 163 (M. Wierzyński). Anna Sosnowska states in her book on Greenpoint that her interviewees mentioned that some of their community leaders had come to the New York City as the agents of the communist intelligence service and that the current ( $21^{\text {st }}$ century) conflicts between the Polish American organizations are inspired by the post-communist intelligence officers. See: A. Sosnowska, Polski Greenpoint..., p. 54-55.

55 P. Reszta, M. Majewski (2014), Zawód szpieg. Rozmowy z Aleksandrem Makowskim, Warszawa: Czarna Owca (Kindle edition). 
Daily Zgoda, the largest Polish language newspaper in the Chicago area, and the closest advisor of Edward Moskal, the president of the Polish American Congress. His collaboration with the communist secret services was revealed by the Polish historians from the Institute of National Remembrance only in the $21^{\text {st }}$ century ${ }^{56}$.

Even if the newcomers were "cleared" and had proven no connections with the intelligence services they were still stigmatized by many Polish Americans for the alleged traces of the communist indoctrination and symptoms of the communist mentality. The very fact that they were accepting any support from the US government testified to this mentality. Old Polonia and World War II cohort thought that if someone was capable of working he/she should have supported himself. One should take any job as soon as possible after arrival and start earning money in order not to become a burden to the society. Accepting aid or - even worse - applying for one, meant that the newcomers got used to relying on the state support and not on themselves, which was a part of the communist upbringing, incompatible with the Polish American world view ${ }^{57}$.

Those who took jobs were accused of poor work ethics, e.g. taking bribes, accepting thefts, cheating the boss - which was also attributed to the legacy of the communist system ${ }^{58}$. Their unwillingness to join the Polish American organizations and any criticism towards them was seen as stemming from the same roots.

Even today, only a minority of the Polish American commentators appreciate the strategy taken up by the newcomers of accepting aid in order to settle down and prepare for a better start in their professional careers (e.g. improving their language, getting their formal education recognized or acquiring new professional skills). These same commentators criticize the traditional Polish American attitude of rejecting available American resources due to an ill-defined ambition ${ }^{59}$.

It has been proven by the researchers that even if the newcomers were using the support of the US government, most of them did it for a short time only and tried to enter job market as soon as possible in order to provide for their families and achieve better living conditions ${ }^{60}$. They were taking jobs below their professional competence and ambitions ${ }^{61}$. They felt that their social status deteriorated and their family relations often suffered ${ }^{62}$. At least the first period in the United States was a traumatic experience for many but gradually the situation im-

${ }^{56}$ His files are at: Instytut Pamięci Narodowej, Warsaw, Poland Wierzewski file, BU 02778/698/D.

57 A. Sosnowska, Polski Greenpoint..., p. 201; J. Cisek, Polish American..., p. 196; M. Erdmans, Opposite Poles..., p. 86-99.

58 See e.g. M. Erdmans, Opposite Poles..., p. 210.

59 Interviews with Chris Long and Lucyna Migała, Chicago, July 2014; see also: J. Wojdon (2017), Trzy polonijne kobiety sukcesu z Chicago, "Studia Migracyjne - Przegląd Polonijny”, Vol. 43, no. 1, p. 103.

60 M. Erdmans, Opposite Poles..., p. 95.

${ }^{61}$ E.g. A. Sosnowska, Polski Greenpoint..., p. 201-203; J. Chołodecki, in: A. Krajewski, Region USA..., p. 37; M. Wierzyński, in: Piątkowska-Stepaniak W. (ed.), Autoportret zbiorowy..., p. 155-157.

${ }_{62}$ M. Erdmans, Opposite Poles... 
proved $^{63}$. In general, as the time passed, many newcomers admitted that they would never achieve comparable living standards in Poland and that all in all they enjoyed their life in the United States. One should also keep in mind that the testimonies analyzed in this text reflect personal experiences of a small number of immigrants that does not have to be typical for the whole group. However, the prevalence of the complaints on the Polish Americans is symptomatic.

It looks like the World War II émigrés repeated the very attitude of the old Polonia that they themselves had experienced in the 1940s and 1950s upon their arrival in the United States: little understanding, little support, little patience from the well-established Polish American communities. Insufficient support that the newcomers felt was not the result of disillusionment of the old Polonia with the "Solidarity" immigration cohort or with individual immigrants but it simply expressed the Polonia's worldview. This would explain why the Polish Americans put so much effort to help "Solidarity" and the Polish people in Poland and did so little for Solidarity immigrants who arrived in the United States. The newcomers were expected to repeat the experiences of the previous immigration waves, starting from the bottom of the social ladder and slowly progressing to higher positions. How they came to terms with the old(er) Polonia and eventually took control over the Polish American institutions still remains to be reconstructed ${ }^{64}$.

\section{References}

\section{Primary sources:}

Connecticut Polish American Archives, New Britain, Connecticut (CPAA)

Błaszczynski, Andre collection

Bogucki family collection

Dubicka-Morawska, Irene collection

Majewski, Karen collection

Ślusarek, Ewa collection

Solidarity International of Connecticut collection

Interviews with Chris Long and Lucyna Migała, Chicago, July 2014.

Immigration History Research Center, Minneapolis, Minnesota

Mazewski, Aloysius papers

Polish American Congress

Instytut Pamięci Narodowej (Institute of National Remembrance), Warsaw, Poland

Wierzewski, Wojciech file (BU 02778/698/D)

Memo to America-the DP Story: The Final Report of the United States Displaced Persons Commission (1952), Washington: Government Printing Office.

${ }^{63}$ H. Doczyk, in: A. Krajewski, Region USA..., p. 66-68; C. Karkowski, Na emigracji..., passim; M. Wierzyński, in: Piątkowska-Stepaniak W. (ed.), Autoportret zbiorowy..., p. 157-181.

${ }^{64}$ In 1989 there were still two separate groups: "One group is the Second World War [immigration] [...] And then there is this later generation, mostly Solidarity". CPAA, Majewski collection, box 1, folder 6, interview with Jerzy Petryniak, Nov. 9, 1989. 
University of Illinois, Chicago, Illinois Łukomski, Kazimierz Papers

University of Wisconsin-Milwaukee Archives, Milwaukee, Wisconsin Polish American Congress. Wisconsin Division: Records, 1948-2003

\section{Secondary sources:}

Blejwas S. (1981), Old and New Polonias: Tensions within an Ethnic Community, „Polish American Studies", no. 2, pp. 55-83.

Blejwas S. (2005), The Polish Singers Alliance of America, 1888-1998: Choral Patriotism, Rochester: University of Rochester Press.

Cisek J. (2003), Polski Komitet Imigracyjny. Polish American Immigration and Relief Committee (PKI-P AIRC) w Nowym Jorku, New York: PAIRC.

Cisek J. (2006). Polish Refugees and the Polish American Immigration and Relief Committee, Jefferson, NC: McFarland.

Erdmans M. (2007), Opposite Poles: Immigrants and Ethnics in Polish Chicago, 1976-1990, University Park: Penn State Press.

Goddeeris I. (2016), Spór o emigrację Polską w XIX w. - odpowiedź autora, „Kwartalnik Historyczny", Vol. 123, no. 2, pp. 321-326.

Hirschman Ch. (2004), The Role of Religion in the Origins and Adaptation of Immigrant Groups in the United States, „International Migration Review”, Vol. 38, No. 3, pp. 1206-1233.

Jaroszyńska-Kirchmann A. (2004), The Exile Mission: The Polish Political Diaspora and Polish Americans, 1939-1956, Athens (Ohio): Ohio University Press.

Kardela P. (2000), Stanisław Gierat 1903-1977: Działalność społeczno-polityczna. Szczecin: Albatros.

Kardela P. (2015), Stowarzyszenie Polskich Kombatantów w Stanach Zjednoczonych w latach 1953-1990, Olsztyn-Białystok: IPN.

Karkowski C. (2016), Na emigracji, Nowy Jork: CreateSpace [printout on request].

Krajewski A. (1989), Region USA: Działacze Solidarności o kraju, o emigracji, o sobie, London: Aneks.

Memo to America - the DP Story: The Final Report of the United States Displaced Persons Commission (1952), Washington: Government Printing Office.

Piątkowska-Stepaniak W. ed. (2003), Autoportret zbiorowy: Wspomnienia dziennikarzy polskich na emigracji $z$ lat 1945-2002, Opole: Wydawnictwo Uniwersytetu Opolskiego.

Reszta P., M. Majewski (2014), Zawód szpieg. Rozmowy z Aleksandrem Makowskim, Warszawa: Czarna Owca (Kindle edition).

Sosnowska A. (2015), Polski Greenpoint a Nowy Jork. Gentryfikacja, stosunki etniczne i imigrancki rynek pracy, Warszawa: Scholar.

Stola D. (2010), Kraj bez wyjścia? Migracje z Polski 1949-1989, Warszawa: IPN.

Wojdon J. (2014), Myths Pertaining to Polish Americans in the Press of the People's Poland, „Ad Americam", vol. 15, pp. 81-89.

Wojdon J. (2015), White and Red Umbrella: The Polish American Congress in the Cold War Era, 1944-1988, Reno: Helena History Press.

Wojdon J. (2017), Building the Community of the Post-World War II Polish Political Exiles in Chicago - Mutual Aid Association of the New Polish Immigration, in: A. Małek, D. Praszałowicz (eds), The United States Immigration Policy and Immigrants' Responses: Past and Present, Franfurt am Main: Peter Lang, pp. 169-185.

Wojdon J. (2017), Trzy polonijne kobiety sukcesu $z$ Chicago, „Studia Migracyjne - Przegląd Polonijny", vol. 43, no. 1, pp. 95-110. 